\title{
ENTEROTOXICITY OF AEROMONAS HYDROPHILA
}

\author{
E. ANNAPURNA AND S. C. SANYAL* \\ Enteric Infection Unit, Department of Microbiology, \\ Institute of Medical Sciences, Banaras Hindu University, Varanasi-221005, India
}

AEROMONAS HYDROPHILA has been isolated from animal excreta, sewage, soil, food, clinical specimens from man, and infections in cold-blooded marine and fresh-water animals (Hugh, 1970; Davis et al., 1973; Annapurna and Sanyal, 1975). These data indicate that human beings in a community are being exposed continuously to this organism. In a preliminary communication Sanyal, Singh and Sen (1975) reported that some strains of $A$. hydrophila isolated from diarrhoeal and non-diarrhoeal subjects and water sources caused accumulation of fluid in ligated gut loops in rabbits. The present study was undertaken with a larger number of strains isolated from man and his environment to see $(a)$ how many gave a positive result, $(b)$ if they produced an enterotoxin, and $(c)$ what histological changes occurred in the gut loop.

\section{MATERIALS AND METHODS}

Organisms. Fifty strains of $A$. hydrophila isolated in this laboratory during a community study of diarrhoeal diseases were used. They were isolated from children and adults with diarrhoea (7), healthy individuals (26), domestic animals (cow, buffalo, goat) and chickens (11), and water (6) from four sources, namely, the handpump of a shallow tube well, the tap of a piped filtered water supply, the river Ganges, and sewage (table I). They were characterised by the method described by Hugh (1970). The toxigenic strain of $V$. cholerae, no. 569B, was obtained from the Haffkine Institute, Bombay. All strains were maintained as stab cultures and did not undergo more than three subcultures.

Ileal loop test. This was done with live cultures, filtrates and crude toxin in ileal loops in adult rabbits (De and Chatterje, 1953) as described earlier (Sanyal, Singh and Sen, 1975). The inoculum was $1 \mathrm{ml}$ of culture filtrate or crude toxin. Culture filtrate or crude toxin of $V$. cholerae 569B was the positive control, and Brain-Heart Infusion Broth (Difco) or isotonic saline was the negative control. Each test was done in three rabbits and 4-6 loops were usually prepared in each. The animals were killed after $6 \mathrm{~h}$.

Passage of bacteria in ileal loops. One strain isolated from a case of diarrhoea and two from healthy individuals that gave no fluid accumulation in repeated tests were used. One $\mathrm{ml}$ of a 3-4 h nutrient broth culture diluted 1 in 10 in saline was injected into a loop. After $6 \mathrm{~h}$ the contents of the loop were removed aseptically and cultured on nutrient agar. Up to six colonies were isolated each time, cultured and inoculated into another loop until the strain gave a positive reaction.

Multiplication of bacteria in ileal loops. The method described by Sanyal, Singh and Sen (1975) was used with four strains isolated from a diarrhoeal case, a healthy individual, an animal and water from a hand-pump. A 3-4 h culture in nutrient broth was diluted 1 in 10 in isotonic saline and $1 \mathrm{ml}$ was inoculated into each loop. Each experiment was done in three rabbits.

Received 22 Nov. 1976; revised version accepted 6 Jan. 1977.

* Present address: Department of Microbiology, University of Birmingham, PO Box 363, Birmingham B15 2TT.

J. MED. MICROBIOL.-VOL. 10 (1977) 
Preparation of culture filtrates. Two $\mathrm{ml}$ of a 4-5 h peptone water culture were inoculated into $50 \mathrm{ml}$ of Brain-Heart Infusion Broth in a $250 \mathrm{ml}$ conical flask. The flasks were incubated at $37^{\circ} \mathrm{C}$ in a shaking water bath $(120$ oscillations per min.) for $18 \mathrm{~h}$. The cultures were centrifuged at $4^{\circ} \mathrm{C}$ for $30 \mathrm{~min}$. at $22000 \mathrm{~g}$, and the supernates were filtered through millipore filters of $0.45 \mu \mathrm{m}$ average pore diameter and stored at $4^{\circ} \mathrm{C}$.

Preparation of toxin. One hundred $\mathrm{ml}$ of basal medium (Finkelstein and Lankford, 1955, cited by Craig, 1966) in a 500-ml conical flask was inoculated from a stock culture and incubated at $37^{\circ} \mathrm{C}$ in a shaking water bath $(120$ oscillations per min.) for $18 \mathrm{~h}$. The culture was centrifuged at $4^{\circ} \mathrm{C}$ for $30 \mathrm{~min}$. at $22000 \mathrm{~g}$. The supernate was saturated to $90 \%$ with ammonium sulphate in an ice bath and centrifuged at $4^{\circ} \mathrm{C}$ for $30 \mathrm{~min}$. at $22000 \mathrm{~g}$. The precipitate was suspended in $10 \mathrm{ml}$ of distilled water and dialysed against it at $4^{\circ} \mathrm{C}$ with $5-6$ changes of water. After estimating the protein content (Lowry et al., 1951) the dialysed crude preparation was stored at $4^{\circ} \mathrm{C}$.

Determination of minimum reacting dose of culture filtrate and crude toxin in ileal loops. Culture filtrates $(0 \cdot 1-2 \cdot 0 \mathrm{ml})$ were inoculated into different loops of each rabbit. The animals were killed after $6 \mathrm{~h}$ and the accumulation of fluid per centimetre of gut was measured. The minimal amount of filtrate causing maximal accumulation of fluid was regarded as the minimal reacting dose. One-ml volumes of different dilutions of the crude toxin in distilled water were tested in the same way and the minimal reacting dose was calculated. All experiments were done in triplicate.

Effect of temperature on culture filtrate. Culture filtrates were heated at different temperatures for various times in a water bath and $1 \mathrm{ml}$ was inoculated into each loop. The animals were killed after $6 \mathrm{~h}$ and the reactions noted. Each culture filtrate was tested in three rabbits.

\section{TABLE I}

Fluid accumulation produced by live cultures of Aeromonas hydrophila in rabbit ileal loops

\begin{tabular}{|c|c|c|c|c|}
\hline \multicolumn{2}{|r|}{ Source of strains } & $\begin{array}{l}\text { Number } \\
\text { of strains }\end{array}$ & $\begin{array}{l}\text { Number } \\
\text { of strains }\end{array}$ & $\begin{array}{l}\text { Fluid accumulated* } \\
\text { and number of }\end{array}$ \\
\hline Man & $\left\{\begin{array}{l}\text { Diarrhoeal disease } \\
\text { Healthy individuals }\end{array}\right.$ & $\begin{array}{r}7 \\
26\end{array}$ & $\begin{array}{r}6 \\
24\end{array}$ & $\begin{array}{l}0 \cdot 5-1 \cdot 0(1) \\
1 \cdot 0-1 \cdot 5(2) \\
1 \cdot 5-2 \cdot 0(3) \\
0 \cdot 25-0.5(6) \\
0 \cdot 5-1 \cdot 0(11) \\
1 \cdot 0-1 \cdot 5(7)\end{array}$ \\
\hline Animals & $\left\{\begin{array}{l}\text { Cow } \\
\text { Goat } \\
\text { Buffalo } \\
\text { Chicken }\end{array}\right.$ & $\begin{array}{l}5 \\
4 \\
\\
2 \\
1\end{array}$ & $\begin{array}{l}5 \\
4 \\
\\
2 \\
1\end{array}$ & $\begin{array}{l}1 \cdot 0-1 \cdot 5(5) \\
0 \cdot 5-1 \cdot 0(1) \\
1 \cdot 0-1 \cdot 5(3) \\
1 \cdot 0-1 \cdot 5(2) \\
0.5-1 \cdot 0(1)\end{array}$ \\
\hline Water & $\left\{\begin{array}{l}\text { Handpump } \\
\text { Tap water } \\
\text { River Ganges } \\
\text { Sewage }\end{array}\right.$ & $\begin{array}{l}1 \\
1 \\
2 \\
2\end{array}$ & $\begin{array}{l}1 \\
1 \\
2 \\
2\end{array}$ & $\begin{array}{l}1 \cdot 5-2 \cdot 0(1) \\
1 \cdot 0-1 \cdot 5(1) \\
1 \cdot 0-1 \cdot 5(1) \\
1 \cdot 5-2 \cdot 0(1) \\
0.5-1.0(2)\end{array}$ \\
\hline & $\begin{array}{l}\text { Positive control } \\
\text { (V. cholerae } 569 \mathrm{~B}) \\
\text { Negative control } \\
\text { (isotonic saline) }\end{array}$ & $\cdots$ & $\ldots$ & $\begin{array}{l}0 \cdot 8-1 \cdot 5(1) \\
0 \text { (none) }\end{array}$ \\
\hline
\end{tabular}

* Range of values (ml per $\mathrm{cm}$ of gut) in three tests. 
Histopathology of ileal loops. Ileal loop tests were done with live cells and culture filtrates of two strains of $A$. hydrophila (nos. 2884 and 10005 ) and $V$. cholerae 569B. Brain-Heart Infusion Broth provided the negative control. The rabbits were killed after $1 \mathrm{~h}, 2 \mathrm{~h}$ and $6 \mathrm{~h}$ and the reactions noted; each loop was immediately removed, cut through its entire length and placed in a Petri dish completely immersed in $10 \%$ formol-saline. A piece of normal gut measuring a few centimetres was removed and treated similarly. The tests were done in triplicate. Sections embedded in paraffin blocks were stained with haematoxylin-eosin, mounted in Canada balsam and examined under the microscope for histological changes.

\section{RESULTS}

\section{Live cultures}

Forty-seven of the 50 strains of $A$. hydrophila caused fluid accumulation in rabbit ileal loops (table I). The range of fluid accumulation per $\mathrm{cm}$ of gut varied from strain to strain. Most strains caused fluid accumulations comparable to those produced by live cultures of $V$. cholerae 569B. The three strains that gave no fluid accumulation (one from a case of diarrhoeal disease and two from healthy individuals) became positive after two serial passages in rabbit ileal loops and caused fluid accumulation comparable to that produced by $V$. cholerae $569 \mathrm{~B}$.

Four strains of $A$. hydrophila isolated from different sources caused no fluid accumulation when $10^{2}$ bacterial cells were used as the inoculum; a small accumulation of fluid was produced with inocula of about $10^{3}$, and maximal accumulation ( $1 \mathrm{ml}$ or more of fluid per $\mathrm{cm}$ of gut) with about $10^{4}$ cells (table II). There was no increase in fluid accumulation when the inoculum was

TABLE II

Relationship between multiplication and production of fluid by strains of Aeromonas hydrophila in ileal loops

\begin{tabular}{|c|c|c|c|}
\hline $\begin{array}{l}\text { Strain number and } \\
\text { source }\end{array}$ & $\begin{array}{l}\text { Viable count of } \\
\text { inoculum }\end{array}$ & $\begin{array}{l}\text { Viable count per ml, } \\
6 \mathrm{~h} \text { after inoculation }\end{array}$ & $\begin{array}{l}\text { Fluid accumulation (range in } \\
\mathrm{ml} \text { per } \mathrm{cm} \text { of gut) }\end{array}$ \\
\hline $\begin{array}{l}20571 \\
\text { (diarrhoeal disease; } \\
\text { man) }\end{array}$ & $\begin{array}{l}2 \cdot 4 \times 10^{1} \\
1 \cdot 3 \times 10^{2} \\
2 \cdot 2 \times 10^{3} \\
2 \cdot 3 \times 10^{4} \\
2 \cdot 4 \times 10^{5}\end{array}$ & $\begin{array}{l}9.9 \times 10^{5} \\
1.5 \times 10^{7} \\
6.4 \times 10^{6} \\
5 \cdot 3 \times 10^{9} \\
4.3 \times 10^{9}\end{array}$ & $\begin{array}{l}0 \\
0 \\
0 \cdot 4-0 \cdot 5 \\
1 \cdot 0-1 \cdot 2 \\
1 \cdot 0-1 \cdot 1\end{array}$ \\
\hline $\begin{array}{l}7888 \\
\text { (healthy human } \\
\text { being) }\end{array}$ & $\begin{array}{l}1.3 \times 10^{2} \\
1.4 \times 10^{3} \\
3 \cdot 2 \times 10^{4} \\
3.8 \times 10^{5}\end{array}$ & $\begin{array}{l}1.5 \times 10^{7} \\
4.8 \times 10^{6} \\
6.3 \times 10^{9} \\
8.4 \times 10^{9}\end{array}$ & $\begin{array}{l}0 \\
0 \cdot 45-0 \cdot 5 \\
0 \cdot 9-1 \cdot 0 \\
1 \cdot 0-1 \cdot 1\end{array}$ \\
\hline $\begin{array}{l}12192 \\
\text { (cow) }\end{array}$ & $\begin{array}{l}1.4 \times 10^{2} \\
2.4 \times 10^{3} \\
1.8 \times 10^{4} \\
3.4 \times 10^{5}\end{array}$ & $\begin{array}{l}3.3 \times 10^{6} \\
1.1 \times 10^{7} \\
7 \cdot 8 \times 10^{8} \\
1.8 \times 10^{9}\end{array}$ & $\begin{array}{l}0 \\
0.3-0.45 \\
0.9-1.0 \\
0.8 \times 1.0\end{array}$ \\
\hline $\begin{array}{l}150 \\
\text { (water; hand pump) }\end{array}$ & $\begin{array}{l}2.0 \times 10^{2} \\
3.4 \times 10^{3} \\
2.3 \times 10^{4} \\
5 \cdot 2 \times 10^{5}\end{array}$ & $\begin{array}{l}5 \cdot 6 \times 10^{6} \\
9 \cdot 9 \times 10^{5} \\
5 \cdot 1 \times 10^{9} \\
6 \cdot 7 \times 10^{9}\end{array}$ & $\begin{array}{l}0 \\
0 \cdot 6-0.8 \\
1.2-1.5 \\
1.2\end{array}$ \\
\hline
\end{tabular}


TABLE III

The effect of temperature on the fuid accumulation produced by culture filtrates in ileal loops

\begin{tabular}{|c|c|c|c|}
\hline \multirow{2}{*}{$\begin{array}{c}\text { Strain } \\
\text { number }\end{array}$} & \multicolumn{2}{|c|}{$\begin{array}{l}\text { Heat treatment of } \\
\text { culture filtrate }\end{array}$} & \multirow{2}{*}{$\begin{array}{c}\text { Range of fluid } \\
\text { accumulated } \\
\text { (ml per cm of gut) }\end{array}$} \\
\hline & Temperature & Time & \\
\hline 2884 & $\begin{array}{l}65 \\
60 \\
60 \\
56\end{array}$ & $\begin{array}{l}10 \\
20 \\
10 \\
20\end{array}$ & $\begin{array}{l}0(0.8-1 \cdot 0)^{*} \\
0(0 \cdot 8-1 \cdot 0) \\
0.8-1 \cdot 1(0 \cdot 7-0.9) \\
0.8-1.0(0.9-1 \cdot 1)\end{array}$ \\
\hline $12192-C_{2}$ & $\begin{array}{l}65 \\
60 \\
60 \\
56\end{array}$ & $\begin{array}{l}10 \\
20 \\
10 \\
20\end{array}$ & $\begin{array}{l}0(0 \cdot 8-1 \cdot 0) \\
0(0 \cdot 8-1 \cdot 0) \\
0 \cdot 9-1 \cdot 2(1 \cdot 0-1 \cdot 1) \\
1 \cdot 0-1 \cdot 1(0.8-1 \cdot 0)\end{array}$ \\
\hline
\end{tabular}

* Ranges for unheated filtrate given in parenthesis.

increased to $10^{5}$ cells. The bacteria multiplied by about $10^{3}-10^{5}$ in all the loops irrespective of the fluid accumulation produced.

\section{Culture filtrates}

The culture filtrates prepared from all of the 50 strains of $A$. hydrophila (three of them after serial passage in rabbit gut) gave positive reactions in ileal loops. Fluid accumulation varied from strain to strain; the amounts of fluid were similar to those obtained in tests with live cultures and there were no significant differences between strains from different sources. The majority caused fluid accumulation comparable to that of $V$. cholerae strain 569B.

Culture filtrates prepared from a strain isolated from diarrhoeal disease and one from a cow were tested in doses ranging from 0.1-2.0 ml. An inoculum of $0.25 \mathrm{ml}$ produced fluid accumulation similar in range to that given by $2 \mathrm{ml}$ of culture filtrate and $1 \mathrm{ml}$ of culture supernate of $V$. cholerae 569B. Culture filtrates prepared from these two strains caused fluid accumulation after heating at $60^{\circ} \mathrm{C}$ for $10 \mathrm{~min}$. or $56^{\circ} \mathrm{C}$ for $20 \mathrm{~min}$. (table III); there was no fluid accumulation after the filtrates had been heated for $10 \mathrm{~min}$. at $65^{\circ} \mathrm{C}$ or $20 \mathrm{~min}$. at $60^{\circ} \mathrm{C}$.

\section{Crude toxin}

The crude toxin prepared from a strain of $A$. hydrophila isolated from a case of diarrhoea caused fluid accumulation of 1.0-1.7 ml per cm of gut. An inoculum of $40 \mu \mathrm{g}$ gave a maximal reaction. A similar preparation from $V$. cholerae 569B was the positive control and $120 \mu \mathrm{g}$ caused comparable fluid accumulation.

\section{Histopathological changes}

No significant difference was observed between the ileal loops exposed to live cells and culture filtrates of $V$. cholerae and $A$. hydrophila for up to $6 \mathrm{~h}$ 
and the normal loops. The intestinal mucosa remained intact and there was no congestion in the blood vessels. Mild mononuclear leucocytic infiltration was noted in the loops exposed to $V$. cholerae and to a lesser extent in those exposed to $A$. hydrophila and in control loops. There was a reduction in the number of goblet cells in the intestinal mucosa of loops treated with both $V$. cholerae and A. hydrophila after exposure for $1 \mathrm{~h}$.

\section{Discussion}

The results of the present study of 50 strains of $A$. hydrophila isolated from man and his environment clearly indicate that the majority of strains are enterotoxic irrespective of the source of isolation. Most of the strains caused accumulation of fluid comparable to that of a toxigenic $V$. cholerae strain. The differences in fluid accumulation between strains may have been due to variation in the release of toxin. Three strains gave negative reactions in repeated tests and later caused accumulation of fluid after only two passages in ileal loops; this would seem to indicate potential enterotoxicity. The initial cultures were probably mixed populations containing a small proportion of toxigenic members and these probably increased in proportion during passage in the loops. However, this observation suggests that in a community where the organisms are in continuous circulation, the ratio of toxigenic to nontoxigenic organisms may be reduced under unfavourable conditions, and enhanced by passage through susceptible hosts.

It was observed that small amounts of fluid accumulated in the ileal loops with inocula of about $10^{3}$ bacterial cells and inocula of $10^{4}$ caused maximal reactions. The bacteria multiplied by about $10^{3}-10^{5}$ in all the loops but accumulation of fluid took place only when the inoculum was $10^{3}$ cells or more. With smaller inocula, no accumulation of fluid was noted even though the bacteria multiplied by about $10^{5}$. Fluid outpouring in ileal loops is considered to be due to liberation of an enterotoxic substance or substances by the organisms during multiplication in the intestine; this has been shown with $V$. cholerae (De and Chatterje, 1953); enteropathogenic E. coli (De, Bhattacharya and Sarkar, 1956), Cl. perfringens (Duncan and Strong, 1969) and V. parahaemolyticus (Sakazaki, Tamura, Nakamura, Kurata, Gohda and Kazuno, personal communication, 1974). The present study indicates that sufficient amounts of enterotoxic substances need to accumulate in the loop to induce fluid outpouring. The negative results with smaller inocula may have been due to the elaboration of less toxic substances during the $6 \mathrm{~h}$ of the experiment. The gradual increase in the range of fluid accumulation corresponded to the increase in size of inocula and indicated that a minimum of bacterial cells was necessary to cause maximal fluid accumulation. This was substantiated by the observation that further increase of the inoculum did not increase the range of fluid accumulation in the ileal loop.

We reported previously that cell-free culture supernates of $A$. hydrophila strains could cause accumulation of fluid in ligated ileal loops (Annapurna and Sanyal, 1975) and this has been confirmed by Wadström, Ljungh and Wretlind 
(1976). In the present study cell-free culture filtrates of all of 50 strains of $A$. hydrophila gave a positive reaction, similar to that of a toxigenic $V$. cholerae strain, indicating that an enterotoxic substance was produced during multiplication in the medium. Heating at $60^{\circ} \mathrm{C}$ for $20 \mathrm{~min}$. and $65^{\circ} \mathrm{C}$ for $10 \mathrm{~min}$. inactivated the biological activity of this substance. It could be precipitated with ammonium sulphate and was non-dialysable. This indicates that, like the cholera enterotoxin and $E$. coli heat-labile enterotoxin, the $A$. hydrophila enterotoxin is protein in nature.

Histological examination of ileal loops exposed to live bacterial cells and culture filtrates of $A$. hydrophila no. 884 for up to $6 \mathrm{~h}$ did not reveal significant changes other than a considerable reduction in the number of goblet cells. This change was noted even in specimens taken after exposure for $1 \mathrm{~h}$ and indicates a depletion of mucus from these cells as described in loops treated with $V$. cholerae (Norris and Majno, 1968; Yardley et al., 1972). The mild mononuclear leucocytic infiltration observed in all the specimens treated with $A$. hydrophila and $V$. cholerae as well as in normal specimens might have been due to surgical manipulation (Moon, Whipp and Baetz, 1971).

While carrying out these experiments it was noted that culture filtrates of A. hydrophila nos. 10005 and 5515, isolated from a buffalo and a non-diarrhoeal child respectively caused blanching of the ileal loop with loss of lustre immediately after inoculation. The phenomenon was observed repeatedly with these two strains but with no other. Accumulation of fluid was not affected. Histological examination of these loops after exposure for $6 \mathrm{~h}$ showed oedema at the tips and base of the villi and in the submucosal tissue; there was no oedema or congestion in loops treated for 1 and $2 \mathrm{~h}$. Similar changes were not noted in tests with the other 48 strains. These observations suggest that a toxic factor was produced by these two strains which was different from the enterotoxin that caused fluid accumulation and further studies are needed to confirm this.

\section{SUMMARY}

Live cells and cell-free culture supernates of 50 strains of Aeromonas hydrophila isolated from diarrhoeic and healthy human faeces, drinking water, sewage, the river Ganges and faeces from domestic animals caused accumulation of fluid in ligated ileal loops of adult rabbits. The amount of fluid produced was comparable to that of a toxigenic strain of Vibrio cholerae. Three of the strains gave positive reactions only after two passages in ileal loops of rabbits. Inocula of about $10^{3}$ viable cells and $0.25 \mathrm{ml}$ of culture supernate caused fluid accumulation in the loops. The enterotoxic factor was inactivated at $60^{\circ} \mathrm{C}$ for $20 \mathrm{~min}$. and $65^{\circ} \mathrm{C}$ for $10 \mathrm{~min}$., was precipitated with ammonium sulphate and was non-dialysable; these results indicate the protein nature of the enterotoxin. An inoculum of $40 \mu \mathrm{g}$ of crude toxin caused as much fluid accumulation as larger inocula. The only histopathological change in the loops was depletion of mucus from the goblet cells.

The authors are grateful to Professor P. C. Sen and Mr S. J. Singh, Department of Microbiology, for their valuable suggestions and to Professor B. Dube, Department of 
Pathology, for his help in histopathological studies. The technical assistance of Mr P. K. Mukherjee, Mr S. N. Pathak and Mr Ram Achal Ram at different stages of the work is gratefully acknowledged.

\section{REFERENCES}

ANNAPURNA, E. AND SANYAl, S. C. 1975. Studies on enteropathogenicity of Aeromonas hydrophila in an experimental model. Indian J. prev. Soc. Med., 6, 234.

CraIG, J. P. 1966. Preparation of the vascular permeability factor of Vibrio cholerae. $J$. Bact., 92, 793.

Davis, B. D., Dulbecco, R., Eisen, H. N., Ginsberg, H. S., Wood, W. B., JR ANd McCarty, M. 1973. Microbiology, 2nd ed., New York, p. 782.

De, S. N., Bhattacharya, K. AND Sarkar, J. K. 1956. A study of the pathogenicity of strains of Bacterium coli from acute and chronic enteritis. J. Path. Bact., 71, 201.

DE, S. N. AND ChatterJe, D. N. 1953. An experimental study of the mechanism of action of Vibrio cholerae on the intestinal mucous membrane. J. Path. Bact., 66, 559.

Duncan, C. L. AND Strong, D. H. 1969. Ileal loop fluid accumulation and production of diarrhea in rabbits by cell-free products of Clostridium perfringens. J. Bact., 100, 86.

Hugh, R. 1970. Pseudomonas and Aeromonas. In Manual of clinical microbiology, edited by J. E. Blair, E. H. Lennette and J. P. Truant, Bethesda, $M d$, p. 175.

Lowry, O. H., Rosenbrough, N. J., Farr, A. L. ANd Randall, R. J. 1951. Protein measurement with the Folin phenol reagent. J. biol. Chem., 193, 265.

Moon, H. W., Whipp, S. C. AND BaETz, A. L. 1971. Comparative effects of enterotoxins from Escherichia coli and Vibrio cholerae on rabbit and swine small intestine. Lab. Invest., 25, 133.

Norris, H. T. AND MajNo, G. 1968. On the role of ileal epithelium in the pathogenesis of experimental cholera. Am. J. Path., 53, 263.

SANYal, S. C., Singh, S. J. AND Sen, P. C. 1975. Enteropathogenicity of Aeromonas hydrophila and Plesiomonas shigelloides. J. med. Microbiol., 8, 195.

WADSTRÖM, T., LJUNGH, A. AND Wrethind, B. 1976. Enterotoxin, haemolysin and cytotoxic protein in Aeromonas hydrophila from human infections. Acta path. microbiol. scand., Sect. B., 84, 112.

Yardley, J. H., Bayless, T. M., Luebbers, E. H., Halsted, C. H. and Hendrix, T. R. 1972. Goblet cell mucus in the small intestine. Findings after net fluid production due to cholera toxin and hypertonic solutions. Johns Hopkins med. J., 131, 1. 